\title{
English Language Anxiety and Motivation Towards Speaking English Among Malaysian Pre-University Students
}

\author{
Hasvinii Ramarow ${ }^{1}$, Norlizah C. Hassan ${ }^{1}$ \\ ${ }^{1}$ Faculty of Educational Studies, Universiti Putra Malaysia, Serdang, Selangor, Malaysia \\ Correspondence: Norlizah C. Hassan, Faculty of Educational Studies, Universiti Putra Malaysia, 43400 UPM \\ Serdang, Selangor, Malaysia. Tel: 603-9769-8210. E-mail: norlizah@upm.edu.my
}

Received: September 3, 2021

Accepted: September 28, 2021 Online Published: October 16, 2021

doi:10.5539/ass.v17n11p207

URL: https://doi.org/10.5539/ass.v17n11p207

\begin{abstract}
This study aims to identify the level of English language anxiety and level of motivation in speaking English among Malaysian Pre-University students. The research sample was composed of pre-university students in Selangor, Malaysia. Using a quantitative research method, the researcher distributed a survey questionnaire which was developed by adapting existing questionnaires by Pappamihiel (2002) for English language anxiety scale and Schmidt, Boraie, and Kassabgy (1996) for motivation. Results of the data analysis established there was a low level of English language anxiety in speaking English among pre-university students, and moderate level of motivation, yet the level of intrinsic motivation was slightly lower than the level of extrinsic motivation in speaking English among pre-university students. The results showed there was a significant correlation between English language anxiety and motivation in speaking language. However, there was no significant difference in gender for English language anxiety and motivation. There was a significant difference on races for English language anxiety and insignificant differences on races for motivation. The findings of this study may serve as a platform for school authorities and policymakers in developing motivation and reducing language anxiety among students.
\end{abstract}

Keywords: English language anxiety, motivation, English language speakers, pre-university students

\section{Introduction}

English is an international language and has been spoken in many countries as native or second and foreign language. Almost in every country the English language has become mandatory to be taught in schools. Thus, in countries like Malaysia, the knowledge of English language is becoming increasingly widespread and those who have good command of English, would help them to broaden the chance of employability in the future, especially for university students (Hanapiah, 2004). The role of policy makers is very important in any sector, mainly in the education system because in order to bring changes and progress in education the policy makers have to put in effort which brings benefits to the people who engage with the education. According to Khemlani, Cavallaro, and Coluzzi (2009), in the year of 2000, after two decades, English was re-implemented as a compulsory subject in pre-university for those students who wish to enrol in local universities.

Initially, Malaysia is one of the Asian countries that is adopting a bilingual system of education. The English subject was introduced as Malaysian University English Test (MUET) and the government made the students sit compulsorily for the examination in order to enter public universities. Miskam and Saidalvi (2018); Khemlani et al., (2009) reported the new policy was introduced in 2002 that Science and Mathematics must be taught in English language in all government schools and later on Miskam and Saidalvi (2018) added that MBMMBI (Uphold Bahasa Malaysia and Strengthen the English Language) was introduced in 2009 for the students to improve English language proficiency level. The coherent explanation was given by the government over the changes that they (Ministry of Education) want to ensure all students should not be left behind in this world of globalization.

In this regard, this article focuses on the influence of affective variables in English language learning. Many of the factors have been identified in the English learning environment, but this article will focus on two major categories of affective factors, namely language anxiety and motivation. In terms of instrumental/integrative motivation, research has revealed strong evidence that an integrative approach to language acquisition is helpful (Ametova, 2020). Anxiety has a substantial impact on second language learners' classroom performance once 
they enter university. Specifically, Malaysian pre-university students will encounter few problems if they score low bands from band one till band three in MUET examination, it might prevent them from entering public universities (Harun et al., 2021). Since MUET is a mandatory requirement, students need to score at least band three, which is considered as good in their speaking skill test (Harun et al., 2021). English-speaking skills are also very important when they start looking for jobs. During the interview, most candidates have to speak in English since it is the medium of interview. When the students do not have good proficiency, they might not get a good job. Hence, mastering the English language is quite important among Malaysian university students. However, some of them are facing problems in learning English due to anxiety and motivation to speak English. There are higher chances for them to have high levels of anxiety and low levels of motivation in learning and speaking English language (Barnes \& Smagorinsky, 2016). Therefore, the primary purpose of this study is to present empirical evidence on English language anxiety and motivation among Malaysian pre-university students. The study has three main aims: first, to determine the levels of English language anxiety and motivation to speak English among Malaysian pre-university students. Second, to examine the relationship between language anxiety and motivation; third, to determine whether there is a substantial difference in language anxiety based on gender and race.

\section{Literature Review}

\subsection{Language Anxiety}

Language anxiety is a difficult and multifaceted phenomenon of self-perceptions, beliefs, feelings, and behaviours connected to language acquisition. It is characterised as a complicated and multidimensional phenomenon of self-perceptions, beliefs, feelings, and behaviours associated with language learning (Kralova, 2016). In the past years, research has shown that language is the specific type of anxiety mostly related with second language acquisition as asserted by Horwitz (2001), who claimed language anxiety can weaken learners' learning process in language learning and raise anxiety among learners. The anxiety that the students experience may have a debilitating impact on their ability to speak out. Thus, this explains that when the students encounter anxiety, it will affect their learning process of language and also gives difficulties in improving their language that they have learned. When the students encounter difficulties in learning, it will automatically develop negative thoughts of themselves in their mind. Cheng, Horwitz, and Schallert (1999) said that students have certain negative assumptions, in the aspect of communication, avoidance of certain kinds of social exchange, and fear of being evaluated. Students are always afraid of their audience that they might judge them negatively or underestimate them when they have low proficiency in language which develops language anxiety.

The theory related to language anxiety was developed by Horwitz in 1986 (Horwitz, 1986). This theory has explained three components of language anxiety which is communication apprehension, fear of negative social evaluation and test anxiety. The first component which is the communication apprehension suggests that language students have mature ideas and thoughts but also have low access to second-language vocabulary when they need to convey a message. The inability to know more vocabulary leads to frustration and apprehension. The second component is fear of negative evaluation. Fear arises due to negative evaluation and because of this, students are not confident of themselves and what they are expressing. They will have a negative assumption that they are unable to make a suitable social impression. The third component is test anxiety, which means students will have fear of academic evaluation. The instructional method requirements of the school and teachers' high expectation on the student's progress lead to test anxiety. These three components lead to a massive negative effect on second-language anxiety (Zheng \& Cheng, 2018).

\subsection{Motivation}

Motivation can be categorized into two major types; intrinsic and extrinsic motivation as claimed by Deci and Ryan (1985). The researchers developed a self-determination theory which related to motivation. In that theory they developed a sub-theory which is Cognitive Evaluation Theory (CET) for intrinsic motivation and Organismic Integration Theory (OIT) for extrinsic motivation. As for the CET, it explains the variability in intrinsic motivation. CET is enclosed in terms of social and environmental aspects that supports and weakens intrinsic motivation. It explains that intrinsic motivation will be catalysed when students are in conditions that lead to their expression. Students with personal interest, who enjoy the language and inherent satisfaction will have a high level of intrinsic motivation. If they do not have any of these, they will tend to have low intrinsic motivation. Plenty of studies have shown that motivation plays an essential role in the success of language learning. In the order to explain the success or failure of any difficult activity, motivation is the key factor. Mitra (2016) said that numerous studies and experiments claimed that second language learners will be successful with the right motivation in human learning. Therefore, it is essential for all parties to focus on the students' 
motivation levels in order to gain success in second language learning.

Study on extrinsic and intrinsic motivation has been widely carried out and the difference between them has been discovered on the importance of both development and educational practices. The most basic intrinsic motivation is humans doing something due to the inherent interest and joy whereas extrinsic motivation is humans doing something because it leads to different or separable outcomes (Ihsan, 2016). Thus, a language learner who is self-motivated to learn a language and chooses to do so of their own will, will be more successful in reaching their goals. Moreover, since humans also have some desires to be part of the community, extrinsic motivation can also be internalised and become a part of learner's intrinsic motivation deals with behaviour of oneself, in order to experience pleasure and satisfaction such as a sense of achievement, self-esteem, being able to use the language appropriately and more. Moreover, Ihsan (2016) claimed that motivation is solely a concept without substantial reality because none has seen motivation and all we have seen is effort, interest, attitude and desire in regard to motivation. On the other hand, extrinsic motivation deals with performing a behaviour which usually ends or involves other consequences of success on the task such as prizes for doing great, getting rewards, a promotion in job and more.

\subsection{Relationship Between English Language Anxiety and Motivation in Speaking English Language}

Several previous studies have found links between English language anxiety and motivation. Liu and Chen (2015) reviewed a study by exploring the association between language anxiety and motivation among Taiwan junior high school students. The researchers found that motivation and anxiety were correlated and motivation can serve as an important predictor of language anxiety. Two motivations, which are eager to learn and speak the language and motivational intensity, contributed to the predictions. They also stated that the speakers with anxiety tend to be more concerned with low motivation which leads to poor proficiency in speaking.

In addition, the study by Nishitani and Matsuda, (2011) investigated the relationship between language anxiety, interpretation of anxiety, intrinsic motivation and the use of learning strategies. The researchers focused on how language anxiety and intrinsic motivation affect the use of learning through the acknowledgement of failure. The findings revealed that students with a high level of intrinsic motivation realized the benefits that they gain from failure and they make use of the learning strategies. In contrast, the students with a high level of language anxiety accredited failure to anxiety and making use of learning strategies to overcome the failure was very less.

As previously written, motivation in language learning and speaking has been researched over the decades. It has been declared that motivation correlates with speaking skill for achieving good proficiency in the language. However, both motivation and anxiety are the variables that might change over the time period. A study conducted by Gardner, Tennant, Masgoret and Mihic, (2004) on language anxiety among a bunch of students learning French language for almost a year. The researcher seeks to decide if and up to what extent the variables that establish in the Socio-Educational Model changed over time. The researcher found that there was a minor change in French used anxiety over a time period, but a major change in anxiety which also relates to language anxiety over the years. There was also serious change in motivational need among the learners and speakers. Additionally, Gardner et al. (2004) figured out that there was some variation in motivation or anxiety across courses. According to their findings, the results showed that students, who have scored an A, have high levels of motivation and low levels of anxiety. Students, who have scored B, have average levels of motivation and anxiety. Both variables were at an equal level. Students, who have scored C to F, have low levels of motivation and high levels of anxiety towards learning and speaking the language. In conclusion, these results demonstrate an inverse relationship between motivation and language anxiety. It summarizes that students with low motivation tend to show low proficiency in speaking and undoubtedly anxiety increases. This could lead to poor proficiency, low self-esteem and low self confidence in order to learn and speak the target language. The conflict and tension that arises from this situation, leads to failure in language learning which results in language anxiety.

\section{Method}

A quantitative survey method was used to gather questionnaires from the sample. The questionnaires were distributed among the respondents to identify their level of language anxiety and level of motivation. Descriptive statistics; means and standard deviation are used to calculate the data of demographic variables such as gender, race, MUET speaking skill result and participants' language proficiency level.

\subsection{Population and Sampling Method}

The population of this study is pre-university students in form six colleges. There are about 77 secondary schools in Selangor which offer form six in their schools and there are about five form six colleges in Selangor. Two form six colleges were chosen by using the snowball method. There are about 366 form six students in both of 
the schools. According to the Raosoft calculator of sampling, a minimum 188 participants were recommended to be used as the sample from the overall population. After filtering the survey result, the researcher managed to collect about 265 completed responses.

Stratified random sampling technique was used as a method of the study. Stratified random sampling technique requires the population to be separated into groups where the respondents are chosen according to those who have taken the MUET examination, based on the suggestion by the schools. Using a quantitative research method, the researcher distributed a survey questionnaire which was developed by adapting existing questionnaires by Pappamihiel (2002) for language anxiety scale and motivation by Schmidt, Boraie, and Kassabgy, (1996). The pilot test has been done on 30 matriculation students, with Cronbach Alpha scored for English Language Anxiety Scale (ELAS) is .84 and Motivation Questionnaire is .71.

\section{Results}

This part presents the profile of the respondents. The demographic information here refers to the gender, race, MUET speaking skill result, and speaking proficiency level of the respondents.

\subsection{Profile of the Respondents}

Table 1 shows the frequency and percentage of the demographic information of gender, race, MUET speaking skill result, and speaking proficiency level of the respondents. The total valid responses were 265 which were collected from the pre-university students in Selangor. There were 38.9\% $(\mathrm{n}=103)$ male and $61.1 \%(\mathrm{n}=162)$ female. Certainly, the number of genders in this study was not equal. Most of the respondents were female. Meanwhile, in terms of races, there were 56.2\% ( $\mathrm{n}=149)$ Malays, $17.0 \%(\mathrm{n}=45)$ Chinese and $26.8 \%(\mathrm{n}=71)$ Indian respondents involved in the study. The data shows most of the respondents were Malays.

The finding of the study shows that $38.1 \%(\mathrm{n}=101)$ respondents took MUET exam before or in session two June/2019, 18.9\% ( $\mathrm{n}=50)$ respondents took MUET exam in session three Sep/2019, 4.2\% ( $\mathrm{n}=11)$ took MUET exam in session Jan/2020, 4.2\% ( $\mathrm{n}=11)$ took MUET exam in session Feb/2020 and lastly $34.7 \%(\mathrm{n}=92)$ took MUET exam in session March/2020 or after that. The number clearly shows that most of the respondents took the MUET session before or in session two June/2019.

The demographic data shows the frequency and percentage of the MUET speaking skill result of the MUET takers. There were $1.5 \%(\mathrm{n}=4)$ respondents got band $1,16.6 \%(\mathrm{n}=44)$ respondents got band $2,38.5 \%(\mathrm{n}=102)$ respondents got band 3,35.5\% $(\mathrm{n}=102)$ respondents got band $4,6.8 \%(\mathrm{n}=18)$ respondents got band 5 and $1.1 \%$ $(\mathrm{n}=3)$ respondents got band 6 . The number visibly shows that most of the respondents got band 3 in their MUET speaking skill test.

Finally, table 1 also shows the frequency and percentage of the proficiency level in speaking English of the respondents. The data shows that $5.7 \%(\mathrm{n}=15)$ respondents speak very well, $42.6 \%(\mathrm{n}=113)$ respondents are in good level, $41.9 \%(\mathrm{n}=111)$ respondents are in okay level and $9.8 \%(\mathrm{n}=26)$ respondents are not okay in speaking English. The finding obviously shows that most of the respondents are good in proficiency.

Table 1. Demographic of the respondents

\begin{tabular}{ccccc}
\hline & & Frequency $(\mathrm{N}=265)$ & Percentage \% & Cumulative Percentage \\
\hline Age & 18 & 14 & 5.3 & 5.3 \\
& 19 & 158 & 59.6 & 64.9 \\
& 20 & 66 & 24.9 & 89.8 \\
& 21 & 27 & 10.2 & 100.0 \\
\hline Gender & Male & 103 & 38.9 & 38.9 \\
& Female & 162 & 61.1 & 100.0 \\
\hline Class level & Lower six & 7 & 2.6 & 2.6 \\
& Upper six & 258 & 97.4 & 56.0 \\
\hline Race & Malay & 149 & 56.2 & 73.2 \\
& Chinese & 45 & 17.0 & 100.0 \\
\hline MUET Session & Indian & 71 & 26.8 & 38.1 \\
& Before or Session 2 June/2019 & 101 & 38.1 & 57.0 \\
& Session 3 Sep/2019 & 50 & 18.9 & 61.1 \\
& Session Jan/2020 & 11 & 4.2 & 65.3 \\
& Session Feb/2020 & 11 & 4.2 & 100.0 \\
\hline
\end{tabular}




\begin{tabular}{ccccc}
\hline MUET speaking & BAND 1 & 4 & 1.5 & 1.5 \\
skill result & BAND 2 & 44 & 16.6 & 38.5 \\
& BAND 3 & 102 & 35.5 & 56.6 \\
& BAND 4 & 94 & 6.8 & 92.1 \\
& BAND 5 & 18 & 1.1 & 100.9 \\
\hline How well do & BAND 6 & 3 & 5.7 & 5.7 \\
you speak in & Very well & 15 & 42.6 & 48.3 \\
the English & Good & 113 & 41.9 & 90.2 \\
language? & Okay & 111 & 9.8 & 100.0 \\
\hline
\end{tabular}

\subsection{Level of English Language Anxiety in Speaking English}

Table 2 shows a descriptive analysis of language anxiety level towards speaking English among pre-university students in Selangor. The finding of the study shows the levels of language anxiety were low and the scores for language anxiety ranged from 0.50 to $2.50(\mathrm{M}=1.5802, \mathrm{SD}=.42232)$

Table 2. English language anxiety level towards speaking English

\begin{tabular}{ccccc}
\hline & Minimum & Maximum & Mean & SD \\
\hline English Language Anxiety & .50 & 2.50 & 1.5802 & .42232 \\
\hline
\end{tabular}

Table 3 shows the level of language anxiety based on the MUET speaking skill results acquired by the respondents. The mean score of Band 1 is $(\mathrm{M}=1.6719, \mathrm{SD}=.56912)$, Band 2 is $(\mathrm{M}=1.8437, \mathrm{SD}=.35394)$, Band 3 is $(\mathrm{M}=1.6513, \mathrm{SD}=.35611)$, Band 4 is $(\mathrm{M}=1.4461, \mathrm{SD}=.40552)$, Band 5 is $(\mathrm{M}=1.2188, \mathrm{SD}=.45690)$ and lastly the mean score of Band 6 is $(\mathrm{M}=1.5417, \mathrm{SD}=.84394)$. Based on the mean score, the table indicates that respondents who got Band 2 were having the highest level of language anxiety and the respondents who got Band 5 were having the lowest level of language anxiety towards speaking English.

Table 3. MUET speaking skill results

\begin{tabular}{cccc}
\hline MUET speaking skill result & Mean & N & .56912 \\
\hline BAND 1 & 1.6719 & 4 & .35394 \\
BAND 2 & 1.8437 & 44 & .35611 \\
BAND 3 & 1.6513 & 102 & .40552 \\
BAND 4 & 1.4461 & 94 & .45690 \\
BAND 5 & 1.2188 & 18 & .84394 \\
BAND 6 & 1.5417 & 3 & .42232 \\
\hline
\end{tabular}

\subsection{Level of Motivation in Speaking English}

Table 4 shows a descriptive analysis of motivation level towards speaking English among pre-university students in Selangor. The finding of the study shows the levels of motivation were moderate and the scores for the motivation ranged from 1.04 to $2.50(\mathrm{M}=2.1210, \mathrm{SD}=.20972)$.

Table 4. Motivation level towards speaking English

\begin{tabular}{cccccc}
\hline & $\mathrm{N}$ & Minimum & Maximum & Mean & Std. Deviation \\
\hline Motivation & 265 & 1.04 & 2.50 & 2.1210 & .20972 \\
\hline
\end{tabular}

Table 5 shows the level of motivation based on the MUET speaking skill results acquired by the respondents. The mean score of Band 1 is $(M=1.9231, S D=.59997)$, Band 2 is $(M=2.1040, S D=.20004)$, Band 3 is $(M=2.1339$, $\mathrm{SD}=.17300)$, Band 4 is $(\mathrm{M}=2.1379, \mathrm{SD}=.21443)$, Band 5 is $(\mathrm{M}=2.0363, \mathrm{SD}=.24942)$ and lastly the mean score of Band 6 is $(\mathrm{M}=2.1795571, \mathrm{SD}=.22536)$. The table certainly indicates that respondents who got Band 6 were having the highest level of motivation and respondents who got Band 1 were having the lowest level of motivation towards speaking English. 
Table 5. Motivation level based on MUET result towards speaking English

\begin{tabular}{cccc}
\hline MUET speaking skill result & Mean & N & Std. Deviation \\
\hline BAND 1 & 1.9231 & 4 & .59997 \\
BAND 2 & 2.1040 & 44 & .20004 \\
BAND 3 & 2.1339 & 102 & .17300 \\
BAND 4 & 2.1379 & 94 & .21443 \\
BAND 5 & 2.0363 & 18 & .24942 \\
BAND 6 & 2.1795 & 3 & .22536 \\
Total & 2.1210 & 265 & .20972 \\
\hline
\end{tabular}

\subsection{Level of Intrinsic and Extrinsic Motivation}

The finding in Table 6 below shows the scores for intrinsic and extrinsic motivation levels towards speaking English among pre-university students in Selangor. Both the intrinsic and extrinsic motivation levels were moderate, the scores for the intrinsic motivation ranged from 0.88 to $2.50(\mathrm{M}=2.1104, \mathrm{SD}=.26886)$ and the scores for the extrinsic motivation ranged from 1.11 to $2.50(\mathrm{M}=2.1258, \mathrm{SD}=.22566)$. However, in comparing intrinsic motivation and extrinsic motivation, the finding indicated that the respondents have less intrinsic motivation than extrinsic motivation. Overall, the result shows that the respondents slightly have more extrinsic motivation than intrinsic motivation

Table 6. Level of intrinsic and extrinsic motivation

\begin{tabular}{cccccc}
\hline & $\mathrm{N}$ & Minimum & Maximum & Mean & Std. Deviation \\
\hline Intrinsic Motivation & 265 & 0.88 & 2.50 & 2.1104 & .26886 \\
\hline Extrinsic Motivation & 265 & 1.11 & 2.50 & 2.1258 & .22566 \\
\hline
\end{tabular}

\subsection{Relationship Between Language Anxiety and Motivation}

The finding in Table 7 below shows the results of the correlation between language anxiety and motivation in speaking English. Pearson Product-Moment Correlation Coefficient $(r)$ was used to analyse the data. The results indicated that there is a positive low significant correlation between speaking anxiety and motivation in speaking English language at .05 level of significance $\left(r=.147^{*}, p=.016\right)$. Hence, the research hypothesis was accepted.

Table 7. Relationship between language anxiety and motivation in speaking English

\begin{tabular}{ccccc}
\hline & & Language Anxiety & Motivation & MUET speaking skill result \\
\hline Language Anxiety & Pearson Correlation & 1 & $.147^{*}$ & $-.372^{*}$ \\
& Sig. (2-tailed) & & .016 & .000 \\
Motivation & Pearson Correlation & $.147^{*}$ & 1 & .027 \\
& Sig. (2-tailed) & .016 & & .659 \\
MUET speaking skill result & Pearson Correlation & $-.372^{*}$ & .027 & 1 \\
& Sig. (2-tailed) & .000 & .659 & \\
\hline
\end{tabular}

\footnotetext{
* Correlation is significant at 0.05 level
}

Besides, the results also indicated that there is a negative and low correlation between language anxiety and MUET speaking skill resulting in the speaking English language. The value shows that there is a significant relationship between language anxiety and MUET speaking skill at .05 level of significance $\left(r=-0.372^{*}, p=.000\right)$. In addition, the results also showed that there is a positive and negligible direction between motivation and MUET speaking skill resulting in speaking the English language. The value shows that there is no significant relationship between motivation and MUET speaking skill at .05 level of significance $(r=0.027, p=.659)$. Hence, the hypothesis of the study fails to be rejected.

\subsection{Difference Between English Language Anxiety and Motivation Based on Gender}

The finding in table 8 below shows the result of the difference of English anxiety and motivation among the pre-university students based on gender. The independent $t$-test was activated to test the difference in gender based on English language anxiety, and as presented in table 8, the finding compares the means of one sample $\mathrm{t}$-test. It shows there is no significant $(\mathrm{t}=-.901, \mathrm{p}<0.05)$ difference between mean of gender (male) score $(\mathrm{M}=-.04791, \mathrm{SD}=.05315)$ and mean of gender (female) score $(\mathrm{M}=-.04791, \mathrm{SD}=.05397)$ for language anxiety at 0.05 level of significance. Hence, the hypothesis of the study fails to be rejected. 
The independent t-test was activated to test the difference in gender based on motivation and as presented in table 8 , there is no significant difference $(\mathrm{t}=.0892, \mathrm{p}<0.05)$ between mean of gender (male) score $(\mathrm{M}=.02355$, $\mathrm{SD}=.02639)$ and mean of gender (female) score $(\mathrm{M}=.02355, \mathrm{SD}=.02594)$ for motivation at 0.05 level of significance. Hence, the hypothesis of the study fails to be rejected.

Table 8. Difference between English language anxiety and motivation based on gender

\begin{tabular}{ccccccccc}
\hline & & $\mathrm{F}$ & $\mathrm{Sig}$. & $\mathrm{t}$ & $\mathrm{df}$ & $\begin{array}{c}\text { Sig. } \\
\text { (2-tailed) }\end{array}$ & Mean & $\begin{array}{c}\text { Std. } \\
\text { Deviation }\end{array}$ \\
\hline $\begin{array}{c}\text { English Language } \\
\text { Anxiety }\end{array}$ & $\begin{array}{c}\text { Equal variances } \\
\text { assumed (M) }\end{array}$ & .574 & .449 & -.901 & 263 & .368 & -.04791 & .05315 \\
\hline $\begin{array}{c}\text { Equal variances not } \\
\text { assumed (F) }\end{array}$ & & -.888 & 208.535 & .376 & -.04791 & .05397 \\
\hline Motivation & $\begin{array}{c}\text { Equal variances } \\
\text { assumed (M) }\end{array}$ & 1.564 & .212 & .892 & 263 & .373 & .02355 & .02639 \\
\hline $\begin{array}{c}\text { Equal variances not } \\
\text { assumed (F) }\end{array}$ & & .908 & 232.473 & .365 & .02355 & .02594 \\
\hline
\end{tabular}

*The mean difference is significant at 0.05 level

\subsection{Difference Between English Language Anxiety and Motivation Based on Races}

The finding in Table 9 below shows an analysis of variance (ANOVA) to measure the difference in races between English language anxiety and motivation among pre-university students in speaking English. As presented in Table 9, there is a significant difference $(F=15.730, \mathrm{p}<0.05)$ for English language anxiety on race at 0.05 level of significance. Mean of race (Malay) score $(\mathrm{M}=1.6657, \mathrm{SD}=.37724)$, mean of race (Chinese) score $(\mathrm{M}=1.6569, \mathrm{SD}=.44066)$ and mean of race (Indian) score $(\mathrm{M}=1.3521, \mathrm{SD}=.42142)$ for language anxiety. Therefore, the hypothesis of the study was rejected.

On the contrary, there is no significant difference $(F=1.836, \mathrm{p}<0.05)$ on race for motivation at level .05 of significance. As indicated in table 9, the mean score of race (Malay) is $(\mathrm{M}=2.1425, \mathrm{SD}=.19766)$, mean of race (Chinese) is ( $\mathrm{M}=2.1009, \mathrm{SD}=.20107)$ and mean of race (Indian) score is $(\mathrm{M}=2.0888, \mathrm{SD}=.23572)$ for motivation. Overall, there is no significant difference, $(F=1.836, \mathrm{p}<0.05)$ between English language anxiety and motivation based on races. Hence, the hypothesis of the study fails to be rejected.

Table 9. Difference between English language anxiety and motivation based on races

\begin{tabular}{ccccccc}
\hline & Race & $\mathrm{N}$ & Mean & Std. Deviation & $F$ & Sig- $F$ \\
\hline English Language Anxiety & Malay & 149 & 1.6657 & .37724 & 15.730 & .000 \\
& Chinese & 45 & 1.6569 & .44066 & & \\
& Indian & 71 & 1.3521 & .42142 & & \\
& Total & 265 & 1.5802 & .42232 & .19766 & 1.836 \\
& Malay & 149 & 2.1425 & .161 \\
& Chinese & 45 & 2.1009 & .20107 & \\
& Indian & 71 & 2.0888 & .23572 & & \\
& Total & 265 & 2.1210 & & & \\
& & & & & & \\
& & & & & \\
& &
\end{tabular}

*The mean difference is significant at 0.05 level

\section{Discussion and Implications}

The findings of the respondents' profile indicated the majority of pre-university students $61.1 \%$ (162) were female compared to male $38.9 \%$ (103). The data also revealed that the majority of the respondents were $56.2 \%$ (149) Malays, 17.0\% (45) Chinese and 26.8\% (71) Indian. The result of the findings showed that the level of English language anxiety in speaking English among pre-university students in Selangor was low. The scores for language anxiety ranged from 0.50 to $2.50(\mathrm{M}=1.5802, \mathrm{SD}=.42232)$. Based on the results, students who got Band 5 in MUET speaking exam have low level of language anxiety, while students who got Band 2 in MUET speaking exam have high level of language anxiety in speaking English. However, the overall result showed that the level of language anxiety is low in speaking English. This finding is consistent with a study by Cheng, Horwitz and Schallert, (1999); Miskam and Saidalvi (2019) who found the level of language anxiety among students is between low to moderate towards speaking English.

There are various reasons why some students score low on English language anxiety, for instance they tend to 
feel shy and afraid of making mistakes while speaking English, or may be the thinking process of the students, the perceptions towards themselves on language learning and so forth. Since the respondents in this study are in their early adulthood stage, they tend to overcome the difficulties or have different mind-set towards themselves which allows them to have low language anxiety although they do not have good proficiency in speaking English. They do not give up on learning the language because they might have understood that without trying to improve, they will not improve their proficiency and fluency in language, which is very important for their career. Researcher believes that the students understand one of the English sayings, "learn from mistake" because without facing the challenges in a positive way, it will never allow the students to learn more and polish their knowledge. Though, it is not only in speaking English but mostly for everything a human does, they definitely need motivation. Without motivation, an individual will not be able to do things positively. Motivation is an important key factor for every human being to be a successful person. Concentrating on success does not always improve motivation, but concentrating on motivation does endorse success. Cheng et al., (1999) noted in their study that, self-confidence among the speakers have made the students to overcome language anxiety. Self-confidence is the belief in the abilities that they are capable of doing things successfully. On the other hand, when a student has a low level of self-confidence, he or she will be in stress because they might assume that they are incapable of doing things well. However, with a low level of language anxiety in speaking English, some of the students will become upset and this will weaken their speaking performance. Thus, it will influence their abilities in expressing their thoughts and opinions in the English language (Cagatay, 2015) and these can affect their willingness to communicate (Wu \& Lin, 2014).

Based on the findings, both intrinsic and extrinsic motivation levels were moderate in speaking English language yet extrinsic motivation in students to speak English was slightly higher than intrinsic motivation. This result was supported by Hong and Ganapathy (2017) and Wu et al., (2014) that students are highly motivated extrinsically (instrumentally) than intrinsically (integratively) in speaking English language. Hong and Ganapathy (2017) added that technically, instrumental motivation has a greater impact on language learning and speaking. The findings showed that there is a significant low relationship between language anxiety and motivation towards speaking English language among pre-university students. This study result was inconsistent with the finding by Liu and Chen (2015), who reported no significant correlation between language anxiety and motivation. The study indicated the students who are likely to experience high levels of anxiety tend to be less motivated in the learning and speaking process. According to a previous study by Djafri and Supra (2018) motivation does not have a substantial impact on foreign language anxiety. Past studies have suggested that the two factors are related; some have found a negative link between motivation and language learning anxiety (Gardner \& MacIntyre, 1993), while others have discovered a potential positive link between highly motivated students and high levels of anxiety (Kitano, 2002).

Evidently, there is a substantial link between speaking anxiety and motivation to speak English. Therefore, it is necessary for language teachers as well as learners to take actions to alleviate anxiety levels, since anxiety turned out to be associated with students' performance in English (Meihua \& Wenhong, 2011). Setting realistic and attainable goals, creating a relaxing classroom environment, sharing language learning experiences and feelings, giving learners more opportunities to use the language, frequently encouraging and praising learners, and so on have all been suggested as effective ways to reduce anxiety. Nonetheless, because the results of the analyses revealed that fear of being adversely assessed might be a good predictor of English performance in the current study, language teachers and students should exercise caution when dealing with anxiety.

According to the findings of the study, there is no significant difference in English language anxiety based on gender. This result was in contrast with the study by Cagatay (2015) and Berhane (2016) that showed a significant difference between these two variables, whereby the male students tend to be less anxious compared to female students that are found to be more anxious in speaking English. However, the current findings of the study is in line with the study by Aizpuru (2020) that found no significant difference in foreign language classroom anxiety between males and females, and also a study by Shi and Liu (2006) that reported there isn't much of a difference between male and female Chinese EFL students. The results showed that the development of anxiety is not different between both genders.

On the contrary, the current study results revealed that there is a significant difference of English language anxiety based on races and no significant difference on motivation based on races. Many researchers have found that language anxiety varies by race and skill level, although the evidence for specific connections between proficiency levels and foreign language anxiety is equivocal (e.g., Shi et al., 2006; Marcos-Llinas \& Garau, 2009). For example, in Shi et al., (2006) study of EFL learners in China among Chinese students, more proficient students tended to be less anxious. So it is difficult to measure the races/ethnic itself, as English language anxiety 
is much related with the proficiency of the students regardless of the races they belong to. In addition, in Marcos-Llinas and Garau's (2009) study of Spanish learners in the U.S., advanced learners regardless of race showed higher levels of anxiety than beginning and intermediate learners. There are various reasons and differences in terms of the context of the study that need to be extensively researched in terms of types of races and motivation. Thus, races and social belonging or cultural integration is another issue that needs to be addressed in second/foreign language education.

\section{Conclusion}

In conclusion, the results of this study will help researchers get a better understanding about language anxiety and motivation of Malaysian pre-university students who are studying English as a second language. While there is no significant difference in English language anxiety by gender, the findings of this study revealed that there is a substantial difference in English language anxiety by race. This provides useful information for policymakers in determining the most effective method of language learning and encouraging Malaysian pre-university students to speak English. It is hoped that the findings of this study would help the Ministry of Education in focusing primarily on the importance of students in mastering a high level of fluency in English language. Thus, assisting policymakers in developing a curriculum specification that will ensure language learning effectiveness. Malaysian students must be prepared with the essential information, abilities, and attitude toward learning English if they wish to become global players in today's highly competitive worldwide market.

\section{Acknowledgments}

We are very grateful to all the participants for their contribution to this research, and to all who had contributed to this study.

\section{References}

Aizpuru, J. I. (2020). Anxiety in foreign language learning: Proficiency and gender under scrutiny (Bachelor's thesis, University of the Basque Country). Retrieved from https://addi.ehu.es/bitstream/handle/10810/ 43307/TFG\%20_Iturricastillo.pdf?sequence=1

Ametova, O. (2020). The influence of integrative motivation and instrumental motivation on learning English as a foreign language. Journal of Critical Reviews. https://doi.org/10.31838/jcr.07.12.164

Barnes, M. E., \& Smagorinsky, P. (2016). What English language arts teacher candidates learn during coursework and practical: A study of three teacher education programs. Journal of Teacher Education, 67(4), 338-355. https://doi/abs/10.1177/0022487116653661

Berhane, G. (2016). Gender differences in foreign language anxiety at an Ethiopian University African. Journal of Education and Practice, 1(1), 1-16.

Çağatay, S. (2015). Examining Efl students' foreign language speaking anxiety: The case at the Turkish State University. Procedia - Social \& Behavioral Sci, 199, 648-656. https://doi.org/10.1016/j.sbspro.2015.07.594

Çelik, Ö., \& Kocaman, O. (2016). Barriers experienced by middle school students in the process of learning English. I. J. of Psychology \& Educational Studies, 3(1), 33-48. https://doi.org/10.17220/ijpes.2016.01.003

Cheng, Y. S., Horwitz, E. K., \& Schallert, D. L. (1999). Language Anxiety: Differentiating writing and speaking components. Language Learning, 49(3), 417-446. https://doi.org/10.1111/0023-8333.00095

Deci, E. L., \& Ryan, R. M. (1985). Intrinsic Motivation and Self-Determination in Human Behavior. Berlin: Springer Science \& Business Media. https://doi.org/10.1007/978-1-4899-2271-7

Djafri, F., \& Supra, W. (2018). Measuring foreign language anxiety among learners of different foreign languages: In relation to motivation and perception of teacher's behaviors. Asian-Pacific Journal of Second and Foreign Language Education, 3(1). https://doi.org/10.1186/s40862-018-0058-y

Gardner, R. C., \& MacIntyre, P. D. (1993). A student's contribution to Second Language Learning: Part II, Affective Factors. Language Teaching, 26, 1-11. https://doi.org/10.1017/S0261444800000045

Gardner, R., Tennant, J., Masgoret A. M., \& Mihic, L. (2004). Integrative motivation: Changes during a yearlong intermediate-level language course. Language Learning, 54(1), 1-34. https://doi.org/10.1111/j.1467-9922.2004.00247.x

Hanapiah, M. F. (2004). English language and the language of development: A Malaysia Perspective. Jurnal Kemanusiaan, 2(1), 106-120.

Harun, H., Bosro, M. Z. M., Palpanadan, S. T., Ibrahim, M. Y., Sohaimi, N. M., \& Jannaton, N. A. L. (2021). 
Malaysian public university students' challenging skills to pass Malaysian University English Test (MUET). AIP Conference Proceedings 2347, 020046 (2021). https://doi.org/10.1063/5.0052712

Hashwani, M. S. (2008). Students' attitudes, motivation and anxiety towards English language learning. Journal of Research and Reflections in Education, 2(2), 121 -144.

Hong, Y. C., \& Ganapathy, M. (2017). To investigate ESL students' instrumental and integrative motivation towards English language learning in a Chinese School in Penang: Case study. English Language Teaching, 10(9), 17-35. https://doi.org/10.5539/elt.v10n9p17

Horwitz, J. L. (2001). The Bootstrap. In J. L. Heckman (Ed.), Handbook of Econometrics (Vol. 5, pp. 3159-3228). Amsterdam: Elsevier Science B.V. https://doi.org/10.1016/S1573-4412(01)05005-X

Horwitz, E. K., Horwitz, M. B., \& Cope, J. (1986). Foreign language classroom anxiety. The Modern Language Journal, 70(2), 125-132. https://doi.org/10.1111/j.1540-4781.1986.tb05256.x

Ihsan, M. D. (2016). Students' motivation in speaking English. https://doi.org/10.21070/jees.v1i1.147

Khemlani, D. M., Cavallaro, F., \& Coluzzi, P. (2009). Language policies impact on language maintenance and teaching: Focus on Malaysia, Singapore, Brunei and the Philippines. The Linguistics Journal, 152-186. Retrieved from https://www.ntu.edu.sg/home/CFCavallaro/Pdffiles/DavidCavallaroandColuzzi 2009.pdf

Kitano, K. (2002). Anxiety in the College Japanese Language Classroom. The Modern Language Journal. https://doi.org/10.1111/0026-7902.00125

Kralova, Z. (2016). Foreign language anxiety. https://doi.org/10.17846/SEN.2015.91-100

Liu, H., \& Chen, C. (2015). A comparative study of foreign language anxiety and motivation of academic- and vocational-track high school students. ELT, 8(3). https://doi.org/10.5539/elt.v8n3p193

Marcos-Llinás, M., \& Garau, M. (2009). Effects of language anxiety on three proficiency-level courses of Spanish as a foreign language. Foreign Language Annals, 42, 94-111. https://doi.org/10.1111/j.1944-9720.2009.01010.x

Meihua, L., \& Wenhong, H. (2011). An exploration of foreign language anxiety and English learning motivation. Education Research International. https://doi.org/10.1155/2011/493167

Miskam, N., \& Saidalvi, A. (2019). Investigating English language speaking anxiety among Malaysian undergraduate learners. Asian Social Science, 15(1), 1-7. https://doi.org/10.5539/ass.v15n1p1

Mitra, A. (2016). The impact of motivation on English language learning. International Journal of Research in English Education, 1(1), 11-15

Nishitani, M., \& Matsuda, T. (2011). The relationship between language anxiety: Interpretation of anxiety, intrinsic motivation and the use of learning strategies. US-China Education Review, 8(2). Retrieved from http://hdl.handle.net/10086/28982

Pappamihiel, N. E. (2002). English as a second language, Students and English language anxiety: Issues in the mainstream classroom. National Council of Teachers of English, 36(3), 327-355.

Schmidt, R., Boraie, D., \& Kassabgy, O. (1996). Foreign language motivation: Internal structure and external connections. In R. L. Oxford (Ed.), Language learning motivation: Pathways to the new century (pp. 14-87). Honolulu, HI: University of Hawaii Pre

Shi, Y. Z., \& Liu, Z. Q. (2006). Foreign language reading anxiety and its relationship to English achievement and gender. Journal of PLA University of Foreign Languages, 29, 59-65.

Wu, C. P., \& Lin, H. J. (2014). Anxiety about speaking a foreign language as a mediator of the relationship between motivation and willingness to communicate. Perceptual and Motor Skills, 119(3), 785-798. https://doi.org/10.2466/22.PMS.119c32z7

Zheng, Y., \& Cheng, L. (2018). How does anxiety influence language performance? From the perspectives of foreign language classroom anxiety and cognitive test anxiety. Language Testing in Asia, 8(13). https://doi.org/10.1186/s40468-018-0065-4

\section{Copyrights}

Copyright for this article is retained by the author(s), with first publication rights granted to the journal.

This is an open-access article distributed under the terms and conditions of the Creative Commons Attribution license (http://creativecommons.org/licenses/by/4.0/). 